\title{
STUDIES ON GLUCORECEPTOR. I. SPECIFIC BINDING OF D- GLUCOSE TO PARTIALLY PURIFIED MEMBRANE OF RAT ISLETS OF LANGERHANS
}

\author{
Kunio Kobayashi, Keiko Yoshida, Yoko Tsumura, Shohei Kagawa, And Akira \\ MATSUOKA
}

Department of Clinical Pathology and Clinical Laboratory, Hyogo College of Medicine, 1-1, Mukogawa-cho, Nishinomiya 663, Japan

(Received June 11, 1979)

Three kinds of plasma membranes in rat islet homogenate were fractionated on sucrose gradient centrifuged at $70000 \mathrm{~g}\left(\mathrm{~F}_{1}: d^{20}=1.14-1.18, \mathrm{~F}_{2}: d^{20}=1.06-1.12\right.$, $\left.\mathrm{F}_{3}: d^{\mathbf{2 0}}=1.02-1.05\right)$. Every fraction indicated both enzyme activities of 5'-nucleotidase and ATPase which were typical marker enzymes in pancreatic plasma membrane, and the D-[5$\left.{ }^{3} \mathrm{H}\right]$ glucose binding with them were dose-dependently inhibited by $\mathrm{D}$-glucose, but not by Lglucose, D-galactose and 3-O-methyl-D-glucose.

The $\mathrm{D}-\left[5^{3} \mathrm{H}\right]$ glucose binding with only $\mathrm{F}_{2}$ fraction was inhibited by $\mathrm{D}$-mannose and D-fructose which could stimulate insulin release $(60 \%)$, phlorizin inhibited remarkably the binding with $\mathrm{F}_{3}$ fraction $(68 \%)$, however, the $\mathrm{D}-\left[5^{-3} \mathrm{H}\right]$ glucose binding with either $\mathrm{F}_{1}$ or $\mathrm{F}_{2}$ fraction was slightly inhibited by preincubation with alloxan $\left(0.2 \mathrm{mg} / \mathrm{ml}, 37^{\circ}, 10 \mathrm{~min}\right)$ $\left(\mathrm{F}_{1}: 29 \%, \mathrm{~F}_{2}: 39 \%\right)$ and that with $\mathrm{F}_{3}$ fraction was not effective $(4 \%)$.

It was found that the insulin release from the $\mathrm{B}$ granules which distributed in the pellet fraction on sucrose gradient centrifuged at $70000 \mathrm{~g}$, was induced by the interaction with $\mathrm{F}_{2}$ fraction.

Each maximal capacity of glucose binding site in $F_{1}, F_{2}$ and $F_{3}$ fractions was estimated at $3.2,1.0$ and $\cdot 3.2 \mu \mathrm{mol} / \mathrm{mg}$ membrane protein, respectively, from those Scatchard's plots for the glucose binding.

Consequently, it was estimated that the membrane which associated with insulin release was contained in $\mathrm{F}_{2}$ fraction among three fractions from the islet homogenate.

Keywords - insulin release; B cell membrane; glucoreceptor; B granules; islet homogenate; $\mathrm{D}-\left[5^{-3} \mathrm{H}\right]$ glucose binding; phlorizin alloxan

\section{INTRODUCTION}

It has been established that D-glucose is an important stimulus for insulin release in vivo ${ }^{1)}$ and in vitro, ${ }^{2,3)}$ and certain other sugars can also be effective. Recent studies on insulin release using the anomers of D-glucose suggested that glucoreceptors may be contained on or in the $\mathrm{B}$ cell membrane. $^{4-6)}$

If there is a glucoreceptor site on or in the B cell membrane, it may be possible to extract and characterize it. Price found that some hexoses which are stimulants for insulin release, formed complex with the solubilized cell membranes of dog pancreatic islets," and also it was tried to purify and characterize plasma membrane-rich fractions from rat pancreatic islets by the ultracentrifugation on sucrose gradient by Lernmark et al. ${ }^{8)}$ However, any distinction between the glucose-recognition site for insulin release (glucoreceptor) and that for glucose transport were not explained.

In order to determine whether glucoreceptor exists on or in the islet cell membranes, we have examined the specific binding of $\mathrm{D}$-glucose with membranes fractionated from rat islet homogenate 
in this study.

\section{MATERIALS AND METHODS}

Reagents — All reagents used were of special grade. D-Glucose, D-mannose, D-fructose, phlorizin and alloxan were products of Wako Pure Chemical Industries, Ltd., Japan. L-Glucose, 3-0methyl-D-glucose and collagenase were obtained from Sigma Chemical Co., USA. Bovine serum albumin (fraction $\mathrm{V}$ ) was purchased from The Armour Laboratories, USA. Adenosine 5'-monophosphate, disodium salt and adenosine 5'-triphosphate, disodium salt were obtained from Seikagaku Kogyo, Ltd., Japan. D-[5- $\left.{ }^{3} \mathrm{H}\right] \mathrm{Glucose}(12 \mathrm{Ci} /$ $\mathrm{mmol}),\left[2{ }^{3} \mathrm{H}\right]$ adenosine $5^{\prime}$-monophosphate, disodium salt $(15.4 \mathrm{Ci} / \mathrm{mmol})$, adenosine $5^{\prime}-\left[\gamma^{-32} \mathrm{P}\right]$ triphosphate, tetraammonium salt $(1.28 \mathrm{Ci} /$ mmol), PCS ${ }^{\circledR}$ scintillator and NCS ${ }^{\circledR}$ solubilizer were obtained from The Radiochemical Centre Amersham, Ltd., England. Insulin RIA kit for radioimmunoassay was a product of Dainabot Radioisotope Laboratories, Ltd., Japan. Standard rat insulin was purchased from Novo Industries, A/S., Denmark. Other reagents used for experiments were products of Wako Pure Chemical Industries, Ltd., Japan.

Isolation of Islets - Pancreatic islets of Langerhans were isolated from overnight fasted Sprague-Dawley rats weighing $180-250 \mathrm{~g}$ by the method of Lacy and Kostianovsky. ${ }^{\text {) }}$

Preparation of Islet Plasma Membranes ${ }^{71}$ -Fresh 700-1000 islets collected from six animals were washed successively, with equal-volume $(0.5 \mathrm{ml})$ of Krebs Henseleit bicarbonate buffer ( $\mathrm{pH} \mathrm{7.35,} \mathrm{KHB-buffer)} \mathrm{and} 50 \mathrm{mM}$ Tris$\mathrm{HCl}$ buffer ( $\mathrm{pH} 7.2$ ) containing $2.5 \mathrm{mM} \mathrm{MgCl}_{2}$ and then islets were homogenized in $0.5 \mathrm{ml}$ of $50 \mathrm{mM}$ Tris- $\mathrm{HCl}$ buffer using a homogenizer (Potter-Elvehjem type) at $0^{\circ}$ for $2 \mathrm{~min}$ at 1000 $\mathrm{rpm}$. The islet homogenate was layered on top of a continuous sucrose gradient $\left(d^{20}=1.00-1.18\right.$, $4 \mathrm{ml})$ in cellulose nitrate tube $(1.2 \times 5 \mathrm{~cm})$. Centrifugation was carried out at $4^{\circ}$ for $2 \mathrm{hr}$ at $70000 \mathrm{~g}$ in SW-50 rotor using a ultracentrifuge (Beckman L3-50, Beckman Spinco, Ltd., USA), and the supernatant was fractionated ( $30 \mathrm{drops} /$ fraction) from the bottom of tube. After each fractionated effluent was diluted with $0.5 \mathrm{ml}$ of $50 \mathrm{mM}$ Tris $-\mathrm{HCl}$ buffer, it was centrifuged at $4^{\circ}$ for $30 \mathrm{~min}$ at $10000 \mathrm{~g}$ (Microcentrifuge-542, Eppendorf, INC., Germany). These pellets were provided for the measurements of enzyme activities and the experiments of $\mathrm{D}-\left[5^{-} \mathrm{H}\right]$ glucose binding.

Measurements of 5'-Nucleotidase and ATPase Activities - 5'-Nucleotidase activity was assayed in duplicate samples, using a modification of the radioassay described by Avruch and Wallach. ${ }^{10}$ ) Each pellet was incubated with $20 \mu \mathrm{l}$ of $50 \mathrm{~mm}$ Tris- $\mathrm{HCl}$ buffer $(\mathrm{pH} \quad 8.5)$ containing $0.2 \mathrm{mM}$ $\mathrm{MgCl}_{2}, \quad 4 \mu \mathrm{M}$ 5'-AMP and $\left[2^{-3} \mathrm{H}\right] 5^{\prime}$-AMP $(630000 \mathrm{cpm})$ at $37^{\circ}$ for $60 \mathrm{~min}$. The separation of liberated adenosine from the incubation mixture was performed by paper electrophoresis (filter paper: Whatman No.1, $0.05 \mathrm{M}$ borate buffer, $\mathrm{pH} 9.2,50 \mathrm{v} / \mathrm{cm}, 45 \mathrm{~min}) .\left[2{ }^{3} \mathrm{H}\right]$ Adenosine was extracted from the paper with $2 \mathrm{ml}$ of $0.1 \mathrm{~N} \mathrm{HCl}$ at $37^{\circ}$ for $2 \mathrm{hr}$, and each $0.5 \mathrm{ml}$ of extracted solution was added to $10 \mathrm{ml}$ of PCS ${ }^{\circledR}$-xylene mixture $(2: 1, \mathrm{v}, \mathrm{v})$.

After the mixture was kept overnight at room temperature, the radioactivity was counted in a liquid scintillation counter (Tri-cart MODEL 2450, Packard Instruments, USA). 5'-Nucleotidase activity was expressed as nmol of adenosine liberated in $60 \mathrm{~min}$ per $\mathrm{mg}$ protein.

ATPase activity was assayed in duplicate samples, using a modification of radioassay described by Lernmark. ${ }^{8}$ ) Each pellet was suspended with $0.1 \mathrm{ml}$ of $50 \mathrm{~mm}$ Tris- $\mathrm{HCl}$ buffer and its $20 \mu \mathrm{l}$ was centrifuged at $4^{\circ}$ for $30 \mathrm{~min}$ at $10000 \mathrm{~g}$. Each fellet was incubated in $0.1 \mathrm{ml}$ of histidine buffer $(\mathrm{pH}$ 7.4) containing $1 \mathrm{mM}$ ATP and $[\gamma$ $\left.{ }^{32} \mathrm{P}\right] \operatorname{ATP}(38000 \mathrm{cpm})$ at $37^{\circ}$ for $60 \mathrm{~min}$. The reaction was stopped by addition of $1 \mathrm{ml}$ of $0.1 \mathrm{~N}$ $\mathrm{HCl}$ containing $4 \%$ charcoal (Norit $\mathrm{A}, \mathrm{w} / \mathrm{v}$ ), $0.2 \%$ bovine serum albumin, $1 \mathrm{~mm}$ sodium phosphate and $1 \mathrm{mM}$ sodium pyrophosphate. All samples were mixed and allowed to stand in ice for $30 \mathrm{~min}$ to absorb unreacted ATP before being centrifuged at $4^{\circ}$ for $30 \mathrm{~min}$ at $10000 \mathrm{~g}$. Five hundred microliters of the supernatant fluid was pipetted into $10 \mathrm{ml}$ of PC$S{ }^{\circledR}$-xylene mixture $(2: 1, v / v)$, and the radioac- 
tivity of $\left[{ }^{32} \mathrm{P}\right] \mathrm{Pi}$ was counted in a liquid scintillation counter. A TPase activity was expressed as $\mu \mathrm{mol}$ of $\mathrm{Pi}$ liberated in $60 \mathrm{~min}$ per $\mathrm{mg}$ protein. Protein determination were made using Lowry method, ${ }^{11}$ ) and bovine serum albumin was used as the standard for the protein determination.

Binding of $\mathrm{D}-\left[5^{-3} \mathrm{H}\right]$ Glucose to Plasma Membrane — The specific binding of D-glucose to islet homogenate was determined after incubations for different periods of time at room temperature $\left(25-27^{\circ}\right)$. Approx. $94 \%$ of maximal binding occurred in the first $30 \mathrm{~min}$ of incubation. Steady-state levels were attained in $60 \mathrm{~min}$ and no further increase in binding was seen at $180 \mathrm{~min}$ (Fig. 1). Therefore, the following experiments of

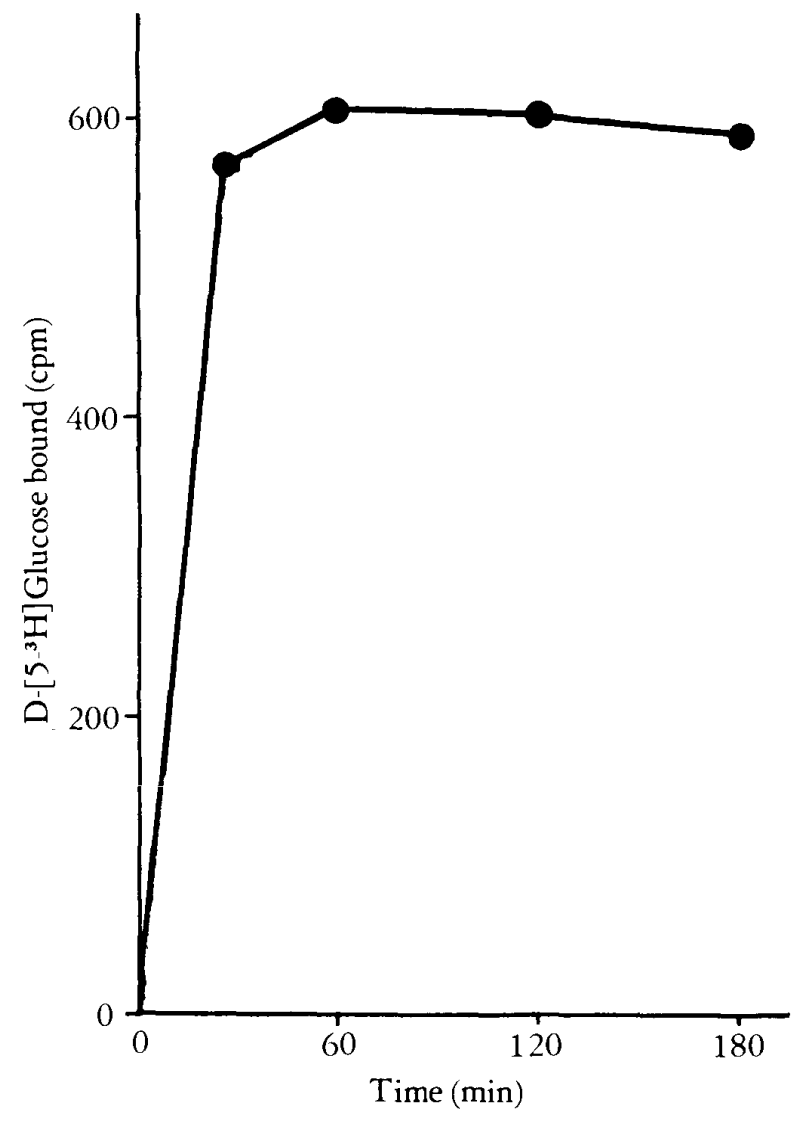

FIG. 1. Time Course of $D-\left[5-{ }^{3} H\right]$ Glucose Binding to Islet Homogenate

The result was derived from the experiments performed using 400 islets. Each point is the mean value of three experiments. The none specific bindings (in the presence of $1 \mathrm{M} \mathrm{D}$ glucose) were about $30 \%$ in each point. glucose binding were carried out for $60 \mathrm{~min}$ at room temperature. Each pellet was suspended with $0.6 \mathrm{ml}$ of $0.1 \mathrm{M}$ Tris- $\mathrm{HCl}$ buffer $(\mathrm{pH} 7.2)$ containing $10 \mathrm{mM} \mathrm{CaCl}, 10 \mathrm{mM} \mathrm{MgCl}_{2}$ and $\mathrm{D}$-[5$\left.{ }^{3} \mathrm{H}\right]$ glucose $(10000 \mathrm{cpm})$, and then $0.6 \mathrm{ml}$ of $0.1 \mathrm{M}$ Tris- $\mathrm{HCl}$ buffer with or without an unlabelled substrate was added. After 60 -min incubation, each mixture was centrifuged at $4^{\circ}$ for $30 \mathrm{~min}$ at $10000 \mathrm{~g}$. Each pellet was kept overnight at room temperature in $10 \mathrm{ml}$ of scintillation fluid, which contained $4 \mathrm{~g}$ of DPO, $0.1 \mathrm{~g}$ of POPOP and $100 \mathrm{ml}$ of NCS $®$ solubilizer per one liter, and then the radioactivity was counted in a liquid scintillation counter.

Effect of Alloxan on $D-\left[5-{ }^{3} \mathrm{H}\right]$ Glucose Binding to Plasma Membrane — Each pellet was suspended with $0.6 \mathrm{ml}$ of $0.1 \mathrm{M}$ Tris- $\mathrm{HCl}$ buffer $(\mathrm{pH} 7.2)$ containing $10 \mathrm{mM} \mathrm{CaCl}_{2}, 10 \mathrm{mM} \mathrm{MgCl}_{2}$, and $0.1 \mathrm{ml}$ of ice-cold solution containing alloxan of 0.4 $\mathrm{mg} / \mathrm{ml}$ concentration was added to $0.3 \mathrm{ml}$ of the pellet suspension. After $10-\mathrm{min}$ incubation at $37^{\circ}$ the reaction mixture was centrifuged at $4^{\circ}$ for 30 min at $10000 \mathrm{~g}$. Each pellet obtained by removing the supernatant was used in the experiments of $\mathrm{D}-\left[5-{ }^{3} \mathrm{H}\right]$ glucose binding.

Sonication of Insulin Secretory Granules ( $B$ Granules) - Each pellet was suspended with 0.5 $\mathrm{ml}$ of cold $\mathrm{Ca}^{2+}$-depleted $\mathrm{KHB}$ buffer, and then centrifuged at $4^{\circ}$ for $30 \mathrm{~min}$ at $10000 \mathrm{~g}$. After this procedure was repeated twice each pellet was sonicated in $0.5 \mathrm{ml}$ of ice-cold $\mathrm{Ca}^{2+}$-depleted $\mathrm{KHB}$ buffer at 80 watts for $15 \mathrm{sec}$. After the centrifugation of the sonicated mixture at $10000 \mathrm{~g}$ for $30 \mathrm{~min}$, the insulin content in the supernatant was determined by a double-antibody radioimmunoassay.

Interaction between $B$ Granules and Fractionated Membranes ${ }^{12)}$ - Each plasma membrane fraction was suspended with $0.6 \mathrm{ml}$ of $0.1 \mathrm{M}$ Tris- $\mathrm{HCl}$ buffer $(\mathrm{pH} 7.2)$ containing $10 \mathrm{mM} \mathrm{CaCl}_{2}$ and $10 \mathrm{mM} \mathrm{MgCl}$, and $0.3 \mathrm{ml}$ of the suspension of membrane was centrifuged at $4^{\circ}$ for $30 \mathrm{~min}$ at $10000 \mathrm{~g}$. After each pellet was washed twice with ice-cold $\mathrm{Ca}^{2+}$-depleted $\mathrm{KHB}$ buffer, it was suspended in $0.25 \mathrm{ml}$ of $\mathrm{KHB}$ buffer containing $10 \mu \mathrm{M}$ ATP, $4 \mu \mathrm{M} \mathrm{CaCl}_{2}$ and $33.4 \mathrm{~mm}$ glucose. On the 
other hand, the pellet(containing B granules) obtained from islet homogenate by a centrifugation for $2 \mathrm{hr}$ at $70000 \mathrm{~g}$ was suspended with $2.5 \mathrm{ml}$ of $\mathrm{Ca}^{2+}$-depleted $\mathrm{KHB}$ buffer. One hundred microliter of the former suspension was mixed with 0.1 $\mathrm{ml}$ of the latter suspension, and was kept at room temperature for $10 \mathrm{~min}$. After the reaction mixture was centrifuged for $30 \mathrm{~min}$ at $10000 \mathrm{~g}$, the insulin content in the supernatant was determined by a double-antibody radioimmunoassay.

\section{RESULTS AND DISCUSSION}

The islet homogenate was centrifuged on a continuous sucrose gradient $\left(d^{20}=1.00-1.18\right)$ for 2 hr at $70000 \mathrm{~g}$. Fig. 2 shows the distribution of the specific activity of total ATPase and 5'-nucleotidase which were marker enzymes in plasma membrane of islets.

It was found that at least three kinds of plasma membranes which were different from each other in specific gravity were present in the islet homogenate.

As shown in Fig. 3, three fractions $\left(F_{1}-F_{3}\right)$ containing plasma membranes bound with $\mathrm{D}-[5$ $\left.{ }^{3} \mathrm{H}\right]$ glucose were separated from the islet homogenate. The distribution of the plasma membrane bound with $\mathrm{D}-\left[5-{ }^{3} \mathrm{H}\right]$ glucose coincided respectively with that of marker enzyme activity in specific gravity. In addition, the binding of $\mathrm{D}-[5$ $\left.{ }^{3} \mathrm{H}\right]$ glucose to plasma membranes in three fractions was significantly inhibited in the presence of $10^{-1} \mathrm{M}$ D-glucose. Therefore, it was proven that each plasma membrane fraction contains a specific binding site with $\mathrm{D}$-glucose.

The $\mathrm{D}-\left[5^{3} \mathrm{H}\right]$ glucose binding with some components in pellet was not inhibited by D-glucose in the medium, therefore, it was speculated that some components in the pellet did not contain any specific binding site for D-glucose.

The dose inhibitory curves for the rate of $\mathrm{D}-[5-$ $\left.{ }^{3} \mathrm{H}\right]$ glucose binding to fractionated plasma membranes by $\mathrm{D}$-glucose are shown in Fig. 4 . The binding of $\mathrm{D}-\left[5-{ }^{3} \mathrm{H}\right]$ glucose with each plasma membrane was dose-dependently inhibited by $\mathrm{D}$-glucose. Since the competitive bindings between $\mathrm{D}-[5$ $\left.{ }^{3} \mathrm{H}\right]$ glucose and unlabelled D-glucose were not significant statistically $(p>0.10)$ at glucose levels

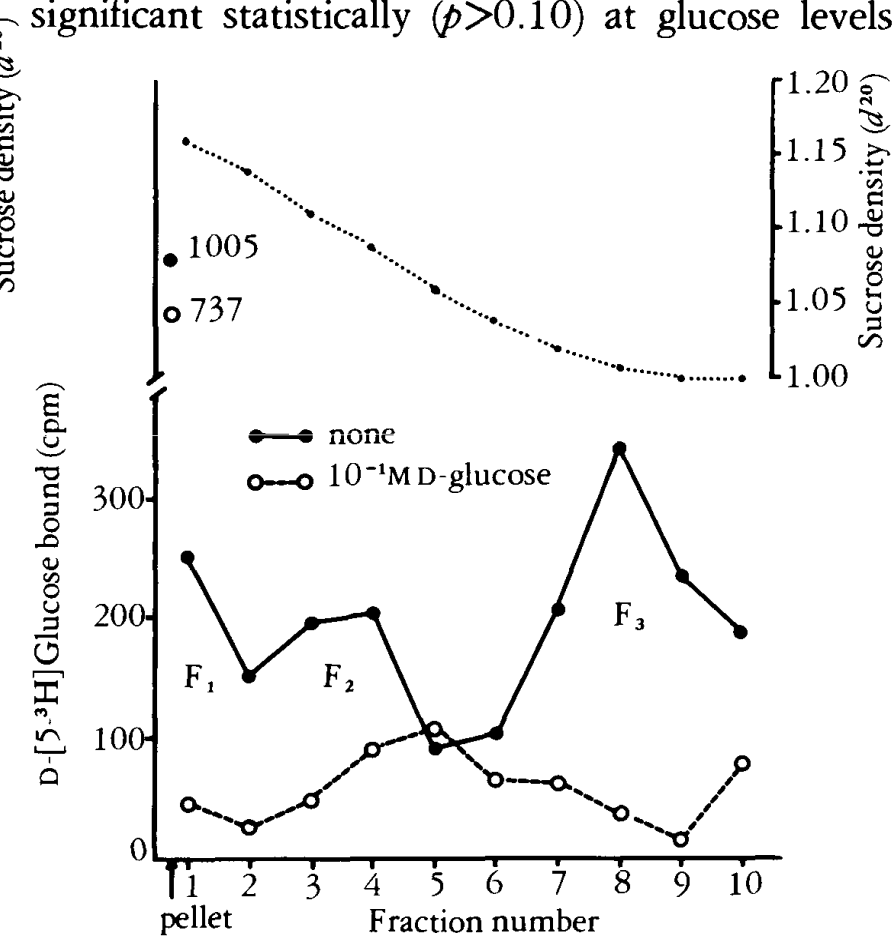

FIG. 3. Distributions of $D-\left[5-{ }^{3} H\right] G$ lucose-bound Membranes

Each curve was derived from the experiment performed using 600 islets.
FIG. 2. Distributions of Total ATPase and 5:Nucleotidase Activities

Each point is the mean value of two experiments.

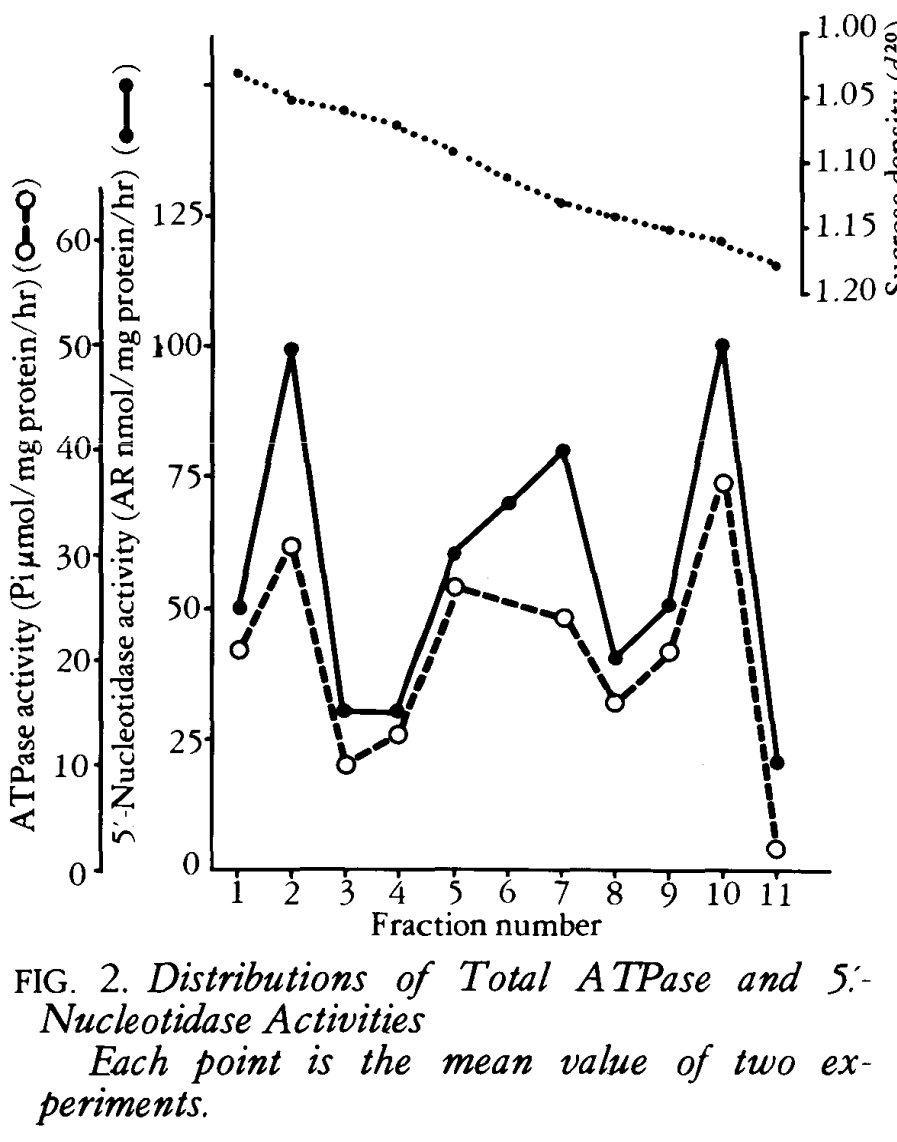


above $10^{-3} \mathrm{M}$ in the three fractions, it was estimated that the binding sites in membrane were saturated with glucose molecules at about $10^{-3} \mathrm{M}$.

The inhibitory effects of several substrates on $\mathrm{D}^{-}$ $\left[5-{ }^{3} \mathrm{H}\right]$ glucose binding with a membrane fractionated from islet homogenate are summarized in Table I. D-Glucose inhibited remarkably the binding of $\mathrm{D}-\left[5-{ }^{3} \mathrm{H}\right]$ glucose to each fraction of $\mathrm{F}_{1}, \mathrm{~F}_{2}$ and $F_{3}$, however, $L$-glucose was not effective. This result suggests that each plasma membrane contains a specific binding site which can distinguish between $\mathrm{L}$ - and $\mathrm{D}$-form as an optical isomer of glucose.

Although neither L-glucose nor 3-O-methyl-Dglucose inhibited the $\mathrm{D}-\left[5^{-3} \mathrm{H}\right]$ glucose binding with all plasma membranes fractionated, either $\mathrm{D}$ -

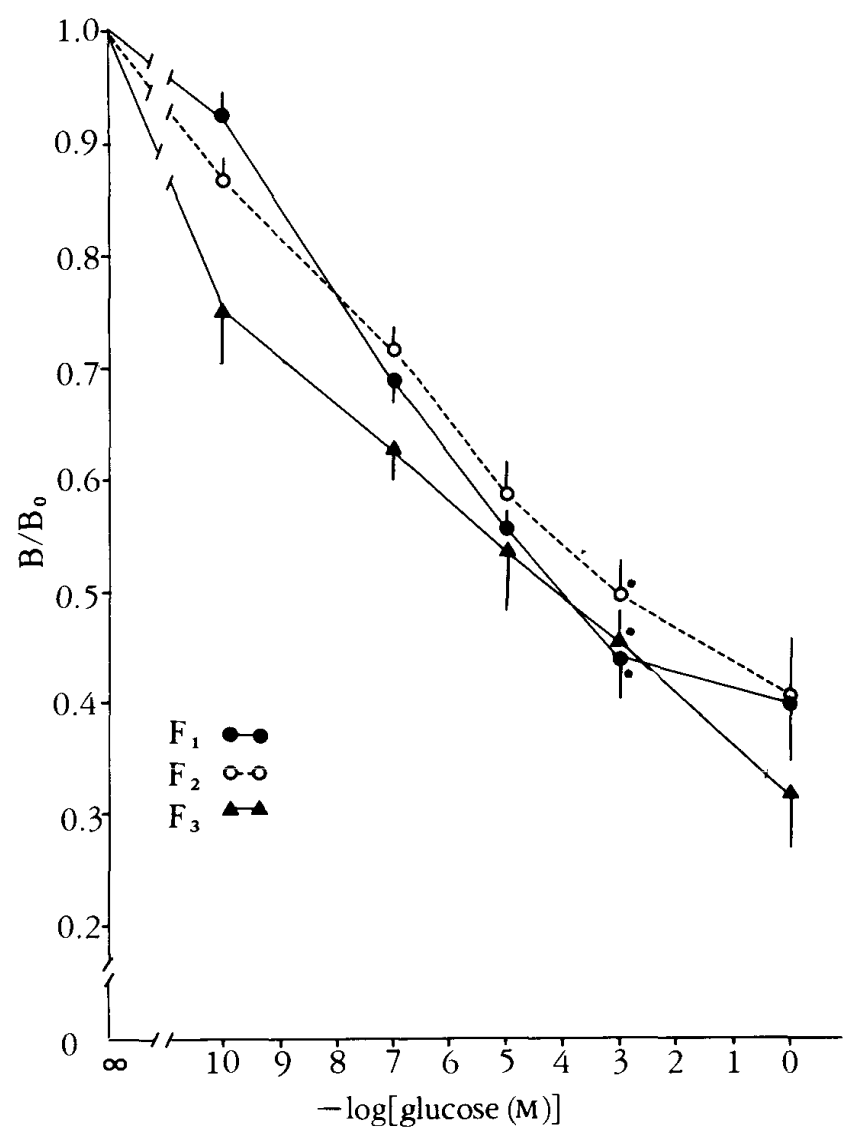

FIG. 4. Displacement Curves for $D-\left[5^{-3} H\right]$ Glucose Binding to Fractionated Membrane by D-Glucose Each point is the mean value ( \pm S.E.M.) of three experiments. ${ }^{*}$ not significant $(0.10<p<0.8)$ compared with the experiment at $1 \mathrm{M} D$-glucose. A series of experiment was performed using about 1000 islets. mannose or D-fructose caused inhibitory effects in $\mathrm{D}-\left[5-{ }^{3} \mathrm{H}\right]$ glucose binding with plasma membrane contained in $\mathrm{F}_{2}$ only, whereas both fractions of $\mathrm{F}_{1}$ and $\mathrm{F}_{3}$ were not inhibited by them.

Since the specific effects of these substrates on the $\mathrm{D}-\left[5^{-3} \mathrm{H}\right]$ glucose binding with membrane in $\mathrm{F}_{2}$ fraction are analogous to that in insulin release from rat islets, it is suggested that the plasma membrane in $F_{2}$ fraction may contain specific site for recognition of sugars involved in insulin release from islets.

Inhibitory effects of $5 \mathrm{mM}$ phlorizin on the D-[5$\left.{ }^{3} \mathrm{H}\right]$ glucose binding with membrane in each fraction were tested here.

Hellman reported that each inhibitory effect of phlorizin on insulin release and glucose transport was $40 \%$ and $70 \%$, respectively in rat pancreatic islets in the presence of $5 \mathrm{mM}$ phlorizin. ${ }^{13)}$ The present results, i.e., the $\mathrm{D}-\left[5^{3} \mathrm{H}\right]$ glucose binding with the membrane in $F_{1}$ and $F_{2}$ fractions decreased to $48 \%$ of control and $68 \%$ in $\mathrm{F}_{3}$ fraction, seem to suggest that the plasma membrane in $F_{3}$ fraction is related to glucose transport and that in $\mathrm{F}_{2}$ fraction is related directly to insulin release.

Each binding of $\mathrm{D}-\left[5^{-3} \mathrm{H}\right]$ glucose with alloxantreated (alloxan $0.2 \mathrm{mg} / \mathrm{ml}, 37^{\circ}, 10 \mathrm{~min}$ ) fraction of $F_{1}$ and $F_{2}$ was slightly inhibited by 29 and $39 \%$, respectively, whereas that with $\mathrm{F}_{3}$ fraction was not affected (4\%).

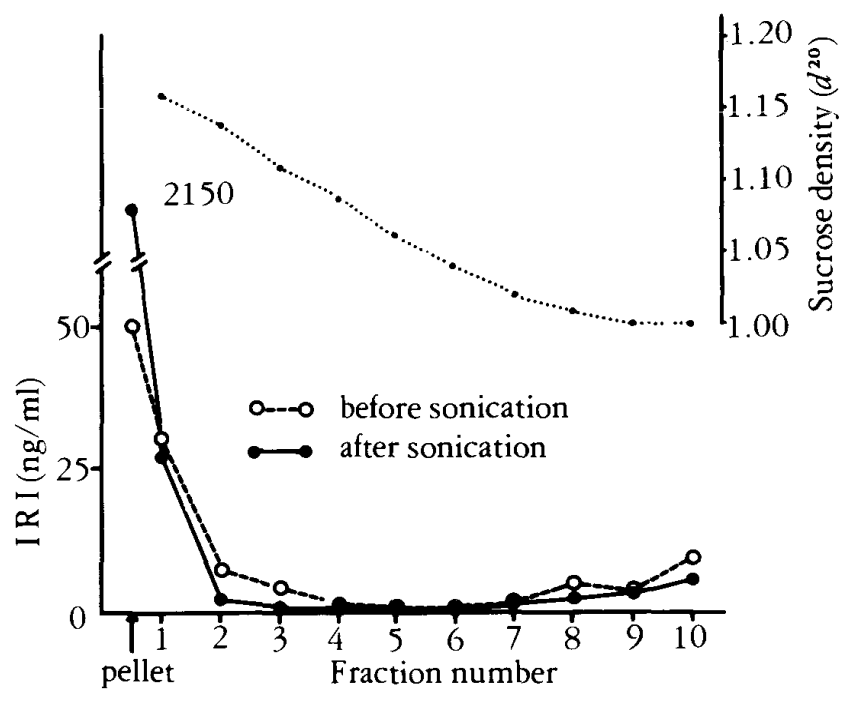

FIG. 5. Distribution of Insulin-secretory Granules (B Granules) 
Lacy demonstrated that the islets preincubated with alloxan $\left(37^{\circ}, 10 \mathrm{~min}\right)$ decreased the glucoseinduced insulin release from the islets to below $10 \%$ of control, and it was not effective in the glucose transport. ${ }^{14)}$ These results suggest also that the membrane in $F_{3}$ fraction is associated with glucose transport system. However, 3-O-methyl$\mathrm{D}$-glucose which can transport into the $\mathrm{B}$ cell did not inhibit $\mathrm{D}-\left[5^{-3} \mathrm{H}\right]$ glucose binding with the membrane in $\mathrm{F}_{3}$ fraction. This finding shows that the $\mathrm{B}$ cell membrane may possess the transport system containing two different binding sites for $\mathrm{D}$-glucose and 3-O-methyl-D-glucose or this membrane fraction may not contain the transport system for $\mathrm{D}^{-}$ glucose.

Fig. 5 shows the distribution of insulin-releasing granules (B granules) in the islet homogenate fractionated on sucrose gradient centrifuged at $70000 \mathrm{~g}$. Usually, B granules are destroyed by the sonication but not by Potter-Elvehjem type homogenizer. We can find a fraction containing B granules by an increase in the insulin content after the sonication of each fraction. The insulin content in the pellet fraction greatly increased from 50 to $2150 \mathrm{ng} / \mathrm{ml}$, therefore, it was found that the B granules were distributed in the pellet fraction.

Lazarus demonstrated that insulin release from

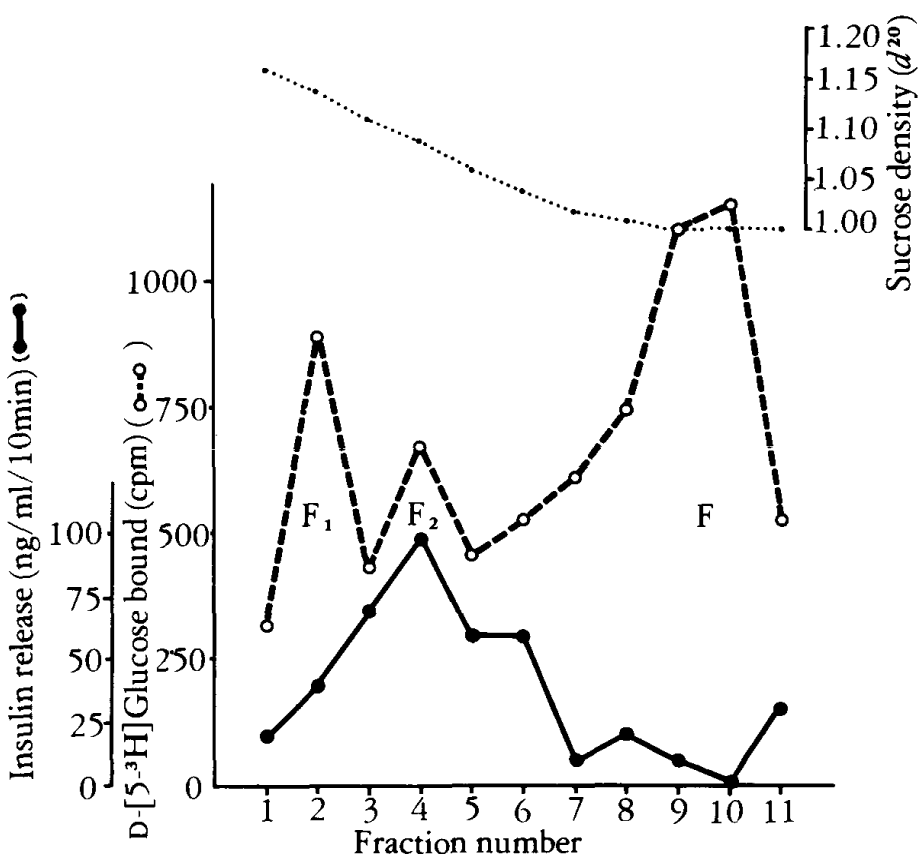

FIG. 6. Distribution of Membranes which causes Insulin Release from $B$ Granules

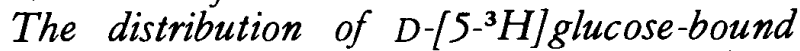
membrane was derived using the same sample as that of insulin release.

TABLE I. Inhibitory Effects of Several Substrates on $D-\left[5^{3} H\right] G l u c o s e$ Binding to Membrane Fractionated from Islet Homogenate

$$
\text { B/Bo (mean } \pm \text { S.E.M. })
$$

Substrate

\begin{tabular}{|c|c|c|c|c|c|c|}
\hline$\left(10^{-1} \mathrm{M}\right)$ & $F_{1}$ & $\mathrm{~F}_{2}$ & $\mathrm{~F}_{3}$ & Pellet & Exp. No & $p$ \\
\hline D-Glucose & $0.26 \pm 0.04$ & $0.47 \pm 0.13$ & $0.24 \pm 0.07$ & $0.78 \pm 0.11$ & (3) & \multirow{6}{*}{$\begin{array}{c}{ }^{*}<0.01 v s . \mathrm{F}_{1} \\
\text { Pellet,D-Gal. } \\
<0.02 v s . \mathrm{F}_{3}\end{array}$} \\
\hline L-Glucose & $0.96 \pm 0.15$ & $0.83 \pm 0.14$ & $0.92 \pm 1.0$ & 1.07 & $(3),(1)$ & \\
\hline D-Mannose & $0.84 \pm 0.08$ & $0.40 \pm 0.01^{*}$ & $0.90 \pm 0.12$ & $0.72 \pm 0.06$ & (3) & \\
\hline \multirow{3}{*}{$\begin{array}{l}\text { D-Galactose } \\
\text { D-Fructose } \\
\text { 3-O-Methyl- } \\
\text { D-glucose }\end{array}$} & $0.71 \pm 0.06$ & $0.72 \pm 0.05$ & $0.84 \pm 0.13$ & $0.96 \pm 0.16$ & (3) & \\
\hline & $0.89-1.05$ & $0.40-0.40$ & $0.89-1.04$ & $0.49-0.58$ & (2) & \\
\hline & $0.85-2.10$ & $0.76-0.93$ & $0.79-1.51$ & $0.59-0.64$ & (2) & \\
\hline $\begin{array}{l}\text { Phlorizin } \\
\left(5 \times 10^{-3} \mathrm{M}\right)\end{array}$ & $0.52 \pm 0.02$ & $0.52 \pm 0.08$ & $0.32 \pm 0.02^{*}$ & 0.81 & $(3),(1)$ & \multirow[t]{2}{*}{${ }^{*}<0.05 v s . \mathrm{F}_{1}, \mathrm{~F}_{2}$} \\
\hline $\begin{array}{l}\text { Alloxan } \\
(20 \mathrm{mg} / 100 \mathrm{ml})\end{array}$ & $0.69-0.73$ & $0.60-0.62$ & $0.92-1.00$ & $1.12-1.29$ & (2) & \\
\hline
\end{tabular}

The inhibitory effect $\left(B / B_{0}\right)$ is expressed as a ratio of $D-\left[5-{ }^{3} H\right]$ glucose bound (cpm) to control (in the absence of substrate). Each result obtained from the experiment using $D$-fructose, 3-O-methyl-D-glucose and alloxan represents the range of two values. 


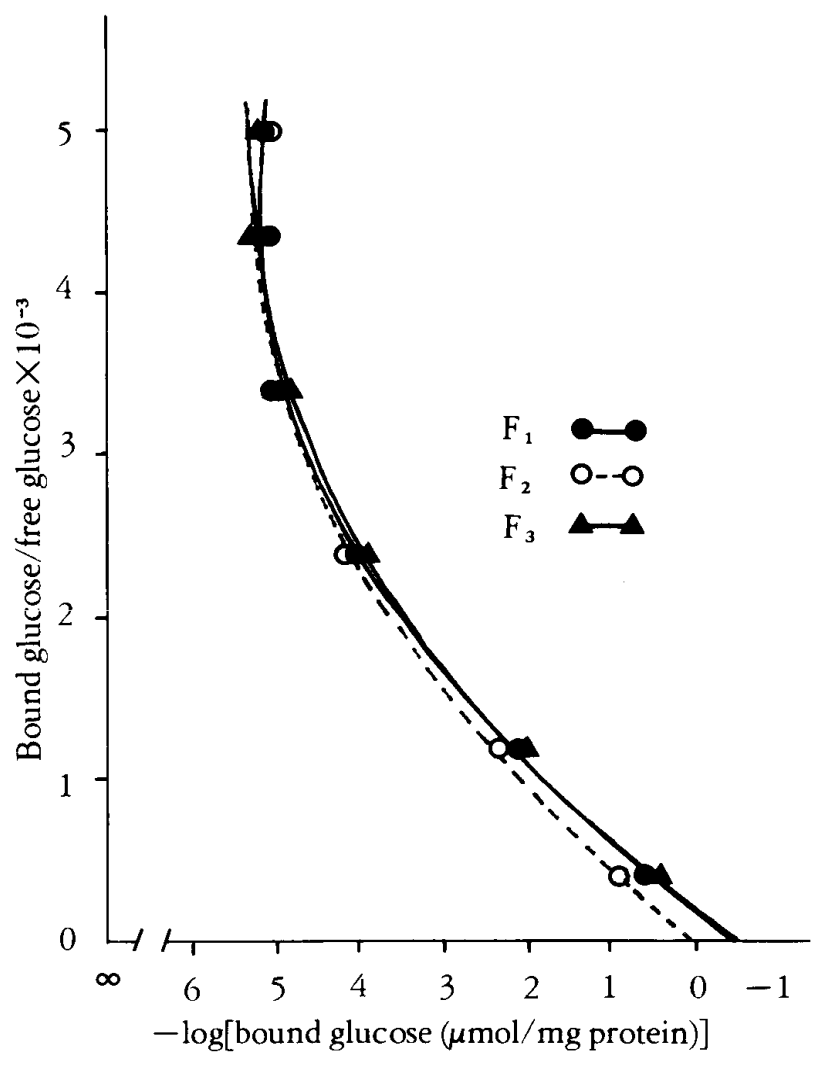

FIG. 7. Scatchard's Plots for D- $\left.15{ }^{3} H\right]$ Glucose Binding to Fractionated Membranes

the B granules was caused by the interaction with islet plasma membrane in the presence of ATP and $\mathrm{Ca}^{2+}{ }^{21}$ Therefore, each fraction was incubated with the pellet fraction containing $B$ granules in the presence of $5 \mu \mathrm{M} \mathrm{ATP}, 2 \mu \mathrm{M} \mathrm{Ca}{ }^{2+}$ and $16.7 \mathrm{mM}$ glucose.

As shown in Fig. 6, the insulin release from the $B$ granules was caused by the interaction with $F_{2}$ fraction only. Accordingly, it was found that the membrane in $F_{2}$ fraction were more closely associated with the glucose-induced insulin release from the islets.

The binding systems of three fractions were characterized more definitively by plotting the ratio of bound glucose to free glucose against the amount $(\mu \mathrm{mol})$ per $\mathrm{mg}$ membrane protein in $60 \mathrm{~min} \mathrm{ac}$ cording to Scatchard et al. ${ }^{15}$ )

As shown in Fig. 7, each curve was represented as a hyperbola that was saturated at $1.0-3.2 \mu \mathrm{mol}$ glucose with the similar slope. Each maximal capacity of binding site in $F_{1}, F_{2}$ and $F_{3}$ fractions was estimated at 3.2, 1.0 and $3.2 \mu \mathrm{mol}$ interacted with $1 \mathrm{mg}$ of membrane protein. Thus hyperbolic profile of Scatchard's plot suggests that a site-site interaction with changes in the affinity occurred between the glucose molecule and the binding site.

Since it is well known that the pancreatic islet of normal rat is not only consisting of B cells but also $A$ and $D$ cells, it will be reasonable to consider that membranes from A or D cells are contaminated with $B$ cell membranes in each fraction. In order to confirm the existence of glucoreceptor on or in the $B$ cell membrane, the purified B cells should be used as the material for experiments.

In conclusion, the present results shows that the islet homogenate contains at least three kinds of cell membranes which have different specific gravity from each other. Furthermore, from both the characteristic properties of $F_{2}$ fraction in the $D$ $\left[5^{3} \mathrm{H}\right]$ glucose binding and the insulin-releasing activity from $B$ granules it is speculated that a glucose recognition site (glucoreceptor) is present in the pancreatic islet.

\section{REFERENCES}

1) J.H.Karam, G.H.Grodsky, K.N.Ching, K.Burill and P.H.Forsham: "Staircase" glucose stimulation of insulin secretion in obesity. Measure of beta-cell sensitivity and capacity, Diabetes, 23, 763-770 (1974).

2) K.Kobayashi, Y.Tsumura, H.Ise, S.Kagawa and A.Matsuoka: Insulin release from the perifused rat Langerhans islets under a slow-rise glucose stimulation, Chem.Pharm. Bull. 25, 2112-2116(1977).

3) H.G.Coore and P.J.Randle: Regulation of insulin secretion studied with pieces of rabbit pancreas incubated in vitro, Biochem.J., 93, 66-78(1964).

4) A.Niki, H.Niki, I.Miwa and J.Okuda: Insulin secretion by anomers of D-glucose, Science, 189, 150-151 (1974).

5) G.M.Grodsky, R.Fanska, L.West and M.Manning: A nomeric specificity of glucose-stimulated insulin release. Evidence for a glucoreceptor?, Science, 186, 536-538 (1974).

6) K.Kobayashi, Y.Tsumura, H.Ise, S.Kagawa, Y.Shinomiya, M.Hata and A.Matsuoka: Insulin response to the $\alpha$ and $\beta$ anomers of $D$-glucose from the perifused rat isolated islets. - Kinetic analysis on insulin response, J.Japan Diab.Soc., 19, 839-846 (1976).

7) S.Price: Pancreatic islet cell membranes: Extraction of a possible glucoreceptor, Biochim.Biophys.Acta, 318, 
459-463 (1973).

8) A.Lernmark, A.Nathaus and D.Steiner: Preparation and characterization of plasma membrane-riched fractions from rat pancreatic islets, J.Cell Biol., 71, 606-623 (1976).

9) P.E.Lacy and M.Kostianovsky: Method for the isolation of intact islets of Langerhans from the rat pancreas, Diabetes, 16, 35-39(1967).

10) J.Avruch and D.F.H.Wallach: Preparation and properties of plasma membranes and endoplasmic reticulum fragments from isolated rat fat cells, Biochim. Biophys. Acta , 233, 334-347 (1971).

11) O.Lowry, N.J.Rosenbrough, A.L.Forr and R.J.Randall: Protein measurement with the Folin phenol reagent, J.Biol.Chem., 193, 265-275 (1951).
12) B.Davis and N.R.Lazarus: An in vitro system for studying insulin release caused by secretory granulesplasma membrane interaction: definition of the system, J.Physiol., 256, 709-729(1976).

13) B.Hellman, A.Lernmark, J.Shehlin and I.B.Täljedal: Effects of phlorizin on metabolism and function of pancreatic $\beta$-cell, Metabolism, 21, 60-66 (1972).

14) M.L.McDaniel, S.Anderson, J.Fink, L.Roth and P.E.Lacy: Effect alloxan on permability and hexose transport in rat pancreatic islets, Endocrinol., 97, 68, 68-75 (1975).

15) G.Scatchard, I.H.Scheinberg, and S.H.Armstrong: Physical chemistry of protein solution.IV. The combination of human serum albumin with thiocyanate ion, J.Am.Chem.Soc., 72, 540-546 (1950). 